\title{
SPECIAL ECONOMIC ZONES (SEZ): CHALLENGES AND OPPORTUNITIES IN NEPAL
}

Gyanwali, Gokarna Prasad ${ }^{4 *}$

\begin{abstract}
The Special Economic Zone (SEZ) is that specific geographical area which has economic and other business laws that are more market-oriented than a country's typical or national laws. It is the region where government provides the special facilities by constructing separate rules and regulations and wants to promote foreign investments and capital for export oriented economy. National laws may be suspended inside a special economic zone. This article describes the different aspects of SEZ in global and national context, policies and present situations of SEZ in Nepal. The overall objective of this article is to find out the present situation of special economic zones of Nepal. The specific objective is to analyze the overall conditions of SEZ, their challenges and opportunities in Nepal. the analytical and descriptive methods are applied in this study. The data used in the study is quantitative which are collected from the economic survey of the ministry of finance, ministry of industry, commerce and supply, World Bank, OECD, SEZ office, published articles and newspapers related to SEZ and reports. In conclusion, to achieve high speed of economic development, to generate employment opportunities and to increase direct foreign investment are the main goals of SEZ. The government of Nepal has implemented formally the concept of Special Economic Zone in 2000 AD and constructed laws, act and policies and implemented after 2017 A D.
\end{abstract}

Keywords: Export processing, Financial capital, Foreign investment, Industrial village, Manufacturing,

\section{Introduction}

Special Economic Zone (SEZ) is the advanced concept of Export Processing Zone, also called the "Free Trade Zones" which includes Export Processing Zones, Special Trade Zones, TourismEntertainment Zones, Information and Technology Parks, Banking etc. These areas include hightech parks, science parks, science and technology zones, green zones and safe zones, among others. However, it remains to be seen if the term SEZs will be adopted by all countries in order to facilitate greater terminology harmonization (Bost, 2019). Sectoral tourism business hub like Bhaktapur, Pokhara, can be tourism economic zone (Badal, 2020).

$4{ }^{*}$ Dr. Gyanwali is associated with Department of Anthropology, Patan Multiple Campus, can be corresponded at gokarna256@gmail.com 
Generally, the aim of SEZs is to attract investment, create employment, and diversify economies, traditionally with a focus on expanding the manufacturing sector (Farole \& Moberg, 2014). Specifically, to develop competitive capacity of export oriented goods and services in the international market; to attract Foreign Direct Investment (FDI); to attract domestic and foreign capital and advanced state of-the-art technology by providing appropriate facility for the industry through one door and to widen the export trade all over the world etc. are the aims of Special Economic Zone (MolCS,N, 2012). Simply, it is the economic region but broadly, it has various and complex definitions. According to Foreign Investment Advisory Service (FIAS, 2008), it is the "demarcated geographic areas contained within a country's national boundaries where the rules of business are different from those that prevail in the national territory. These differential rules principally deal with investment conditions, international trade and customs, taxation, and the regulatory environment; whereby the zone is given a business environment that is intended to be more liberal from a policy perspective and more effective from an administrative perspective than that of the national territory". Similarly, Topno (2005) mentioned that, it is a specifically delineated duty-free enclave and shall be deemed to be foreign territory for the purposes of trade operations and duties and tariffs. In other words, SEZ is a geographical region that has economic laws different from a country's typical economic laws.

In terms of meta-denomination, the emerging consensus is that the term special economic zone is both the broadest and the most precise to describe the zones defined here. It is also particularly useful from a definitional and policy development perspective, as the component terms are themselves both sufficiently broad and precise: 1 . Special refers to the differential regulatory regime that distinguishes the zone from the prevalent domestic economy. 2. Economic refers to the broadest type of activities now allowed in zones, without prejudice regarding their nature and focus. 3. Zone refers to the physically or legally bounded "economic space" contained in the domestic territory (Baissac, 2011). But it is not only based on the terminological meaning as mentioned here. Usually the goal of SEZ is to increase foreign investments. It is proved that, SEZs are the milestones for economic development and have been established in several countries, including China, India, Jordan, Poland, Kazakhstan, Philippines and Russia. North Korea has also att has also attempted this to a degree. In Nepal, first special economic zone was declared by the government in 2014 in Bhairahawa to attract significant investment and to generate economic impact beyond their confines, but six years after it was built, its performance remains below expectations and still in construction phase. 


\section{Objectives}

The overall objective of this article is to find out the present situation of special economic zones of Nepal. The specific objective is to analyze the overall conditions of SEZ, their challenges and opportunities in Nepal.

\section{Methods and data source}

Regarding the objectives, the analytical and descriptive methods are applied in this study. The data used in the study is quantitative which are collected from the economic survey of the ministry of finance, ministry of industry, commerce and supply, World Bank, OECD, SEZ office, published articles and newspapers related to SEZ and reports of International organizations as well as national organizations. The study is based on secondary sources.

\section{Global Practices of SEZ}

The first Special Economic Zone was founded in 1937, in New York, USA in the name of foreign trade zone. But modern-day like zone was first established in 1959 in Shannon, Ireland. Following its success, the model was replicated in various economies such as China, India, Singapore, Taiwan, and Iceland (Pakdeenurit, Suthikarnnarunai \& Rattanawong, 2014). One of the earliest and the most famous SEZs was founded by the government of the People's Republic of China under Deng Xiaoping in the early 1980s. The most successful SEZ in China is in Shenzhen (Tripathi, 2007), following with Zhuhai, and Shantou in Guangdong province and Xiamen (Amoy) in Fujian province. The success of these zones in promoting exports and bring industrial transformation in developing countries led other developing countries to follow the same path. The International Labour Organization's database grew from 176 SEZs in 47 countries in 1986 to 3,500 SEZs in 130 countries 20 years later (ILO, 2018). Soon the number of zones increased from 79 in 1975 to 845 in 1997, and by 2019 there were 5400 functioning SEZs in 147 economies of the world, and 500 were in the pipeline (UNCTAD, 2019).

SEZs have a long history in some Greater Mekong Subregion (GMS) member countries. An early stage in the PRC's "open door" policy saw the creation of four SEZs in coastal cities in 1980, and since then hundreds of special zones with a variety of titles have been established. Viet Nam has also been active in creating special zones, and in 2014 reported having a total of 27 border economic zones (ADB, 2014). In Viet Nam, SEZs play a key role in the government's FDI attraction strategy. There are currently 295 industrial parks, 3 technology parks and 15 economic zones, which concentrate over $50 \%$ of total FDI and $80 \%$ of manufacturing FDI. Similarly, in Lao PDR, SEZs 
have been developed since the early 2000s but remain a relatively new concept. Ten zones have been created, and two seem to be fully operational. In the same way, Philippines hosts well over 300 economic zones administered by the 18 different investment promotion agencies which have contributed significantly both to FDI inflows and to exports. In Cambodia, the legal framework for SEZs was established in 2005. There are currently 34 approved SEZs, of which 14 were operational as of September 2015. Myanmar opted early on in its reform process to develop SEZs to attract foreign investment. (UNIDO, 2015). SEZs are well developed in this region which has been creating measurable employment opportunities since the establishment period. Indonesia employ about $2.5 \%$, Vietnam employ approximately $2.5 \% 1.25 \%$ in the Philippines and $1.1 \%$ in Thailand of total workforce. By 2015, all GMS countries had embraced SEZs in principle, although it is not always clear how successfully they have been implemented (ADB, 2018). Special Economic Zone was more popular in USA which have been more than 257 FTZs and 545 FTZ Subzones in the USA (Pakdeenurit \& Suthikarnnarunai, 2017).

SEZ are not developed in South Asia in comparison to ASEAN countries. In South Asia, India's experience with SEZs dates back to the 1960s, the first country in South Asia to experiment with zones; its first EPZ (not SEZ) was in Kandla, Gujarat, in 1965. After that, Bangladesh (1971), Sri Lanka (1978), Pakistan (1970s), Bhutan (2018), Maldives (2014), Afghanistan (2014), and Nepal (2013) has started to established the SEZ. At 2019, there are 456 SEZs are operational, more than 60 per cent of which specialize in ICT-related manufacturing and services in South Asia. The number of SEZs in South Asia is set to increase substantially in the coming years. India has 373 SEZ are in function and more than 200 new zones in the pipeline, although growth may lose momentum now that permits for a substantial number of zones have been retracted. In Bangladesh, eight public and one private EPZ are all specialized SEZs and further 60 SEZs are in the approval process. Pakistan is planning another 39 SEZs, in addition to its existing nine. Nepal, which has two zones, one of which is under construction, has plans to create 12 more. Similarly, there are 12 SEZ in Srilanka and 3 in Bhutan (WIR, 2019).

\section{SEZ in the Context of Nepal}

Nepal has formally initiated the concept of export oriented trade through the eighth five-year plan (1992-97). After that other various policies of Nepal directly or indirectly mentioned the export oriented trade in Nepal. Some of them are: Environment Policy, Investment Policy, Transit and Logistics Policy, Transport and Trade Facilitation Policy, Bilateral/Multilateral Trade and Transit Treaties, GATT/WTO, SAFTA, BIMSTEC as well as Nepal India and China Rail Services Agreement etc. Similarly, Nepal amended some other relevant acts and regulations for international trade, 
some of them are: Private Financing Act 2006-BOT, Foreign Investment Policy and Technology, Land Acquisition Act-1977, Environment Protection Act/Rules-1997, Export and Import Act-1957, Customs Act-2007, Motor Vehicle Act-1993, Labor Act-1992, Land use policy- 2015 as well as some SEZ policies. (NITDB, 2012).

The government of Nepal has implemented formally the concept of Special Economic Zone in 2000 after acquiring 55 bighas of land in Bhairahawa (manufactured mineral-based products and kitchen utensils). After that, the government has built first Export Processing Zone (EPZ) in Simara (Garment Processing Zone) near the Nepal-India border town of Birgunj (Department of Export, 2019). The government also has plans to establish SEZ in all provinces and the Ministry of Industry has completed the feasibility study for it. The locales are in Biratnagar for Province 1; Simara for Province 2; Panchkhal for Province 3; Gorkha for Province 4; Jumla for Province 6 and Dhangadhi for Province 7. Bhairahawa SEZ in province 5 has already come into operation. The detail of proposed SEZ is given in table no. 1.

Table no. 1: Provincial SEZ in Nepal

\begin{tabular}{|l|l|l|}
\hline \multicolumn{1}{|c|}{ Province } & \multicolumn{1}{c|}{ Location } & \multicolumn{1}{c|}{ Areas of Land (Bighas) } \\
\hline 1 & Damak, Jhapa & 2,600 \\
\hline 2 & Murtiha, Sarlahi & 1,565 \\
\hline Bagmati & Mayurdhap, Makawanpur & 300 \\
\hline Gandaki & Chyalingtar, Gorkha & 300 \\
\hline Lumbini & $\begin{array}{l}\text { Motipur (Rupendehi), Naubasta (Banke) } \\
\text { Dharna and Laxmipur (Dang) }\end{array}$ & $1,877.55$ \\
\hline Karnali & Surkhet & 1,000 \\
\hline Sudur Pachhim & Daiji, Kanchanpur & 900 \\
\hline
\end{tabular}

Source: Ministry of Industry, Commerce and Supplies (2019)

Out of these, Bhairahawa (Rupandehi district, Bagaha); Simara (Bara district); Panchkhal (Hokse) ; Biratnagar (Amaduwa); Kaspilvastu (Sauraha); Jumla (Pandugupha); Dhangadi (Shreepur); Nuwakot (Ratmate, Jilling); Nepalgunj (Naubasta); Jhapa (Ratuwamai Forestry Land,Topganchhi) ; Dhanusha (Umaprempur); Rautahat (Jhunkhunwa); Siraha (Gobindapur) and Gorkha (Deurali) (SEZ, n.d.) also SEZs purposed by the government of Nepal. Among these, government has started the construction work in Jumla and Panchkhal, completed a detailed engineering study of the Biratnagar Special Economic Zone and conducted feasibility studies for zones in other specify SEZs (Khanal, 2019). Now, there are four dry ports at Nepal- India border area on Birjung, Biratnagar, Bhairawa and Kakarvitta which were developed in 2000 and 2010 with the assistance of World 
Bank and Asian Development Bank. Similarly, there are two dry ports at Rasuwa and Tatopani in Nepal -China border with the economic and technical assistance of people republic of China. The only cross-border SEZ established by the government has come into operation since 2018. The SEZ has called for request for proposal from other firms interested to set up industries in Bhairahawa SEZ. Altogether 19 industries have booked 55 plots, out of the total 69 plots in Bhairahawa SEZ. The remaining plots will be sold to interested and eligible firms to set up industries (Joshi, 2073). Similarly, the government of Nepal also amended the special economic zone regulation, 2074. The regulation describes the various sub-rules and provisions related to the SEZ as well as CBSEZ in Nepal.

\section{SEZ in Development Plans of Nepal}

Economic planning had begun in Nepal with the initiation of the First Plan in 1956 AD (2013 BS). The year 1956 AD is viewed as a brilliant year in the planned development exertion of Nepal. Nepal has so far finished fourteen periodic plans and has propelled the Fifteenth Five Year Plan. From tenth five-year plan (2002-2007), Nepal had initiated the concept of Special Economic Zone (SEZ). In tenth five-year plan, feasibility study has carried out to establish Special Economic Zones. During the $11^{\text {th }}$ three-year plan (2007-10), efforts has made to receive foreign aid to established Special Economic Zone in Birgunj; establishment of integrated custom check posts in Nepalgunj, Bhairahawa, Birgunj and Biratnagar as well as an additional dry port (ICD) has constructed at Kakadbhitta. Similarly, 12th three-year plan (2010-2013) has built the infrastructure for Special Economic Zone in Bhairahawa and the land acquisition activity and surrounding wall construction work in Simara is completed. The bill on Special Economic Zone presented in Parliament for ratification. In 13th three-year plan (2013-2016), the construction of the infrastructure was in completion stage and has begun in Special Economic Zone in Bhairahawa, Simara and 12 other places as well as the construction of link roads and expansion of power transmission lines linking possible sites for the cement industry is being carried out under the Industrial Infrastructure Development Programme. In 14th five-year plan (2016-2019), among total Special Economic Zones, 10 were in operation and 9 were under development as well as economic corridors began to constructed in major highways. Similarly, the recent 15th five-year plan (2019-2024) has purposed to establish and operationalization of inter- country Economic zones, Industrial zones, and Industrial villages including mines. If we reviewed the activities regarding the SEZ from $10^{\text {th }}$ to $15^{\text {th }}$ development plan, Nepal has only formulated some policies and only constructed some infrastructures for Special Economic zones. In this 18-year period, Bhairawa and Simara Special Economic zones are started to operatinalization and other are under construction. Such a reality is the background from where the fifteenth development Plan has come into the effect from the 
fiscal year 2019/20 and there is the question will it achieve the goal for SEZ or not?

\section{Budgetary aspects of SEZ}

Priority of budget (FY 2019-20 and FY 2020-21) has been given to operationalise quickly at least one industrial estate in each of the provinces where there were no industrial estates in operation. The work on building industrial estate infrastructure in Damak of Jhapa, Motipur of Rupandehi, Mayurdhap of Makawanpur, Shaktikhor of Chitwan, Naubasta of Banke, Chaurase of Surkhet and Daiji of Kanchanpur has intensified. Basic infrastructure has been assured in Special Economic Zones under construction to encourage investment. Industries' manufacturing basic goods has been encouraged to establish and expand its capacity. The capacity of Udayapur and Hetauda cement industries has increased. Special Economic Zones and Inland Economic Zones has been established and expanded for establishing export-oriented industries in public private partnership. Budget has been allocated for establishing special economic zones in Nuwakot and Panchkhal of Kavre. Although, SEZ has high priority in the plans and budget of the government but the expenditure pattern is very poor. For example, last fiscal year (2019-20), the government had allocated Rs1.38 billion budget for the special economic zone but only Rs720 million was spent. This fiscal year, the government has allocated Rs 820 million budget for the economic zone in Bhairahawa but not a single rupee has been spent. This indicates the poor expenditure and the implementation pattern of the government.

\section{Legal framework of SEZ}

The concept of the SEZ and enactment of the Act are in line with a number of other acts and policies. The Industrial Policy 2010 incorporated the features where export oriented industries and industries based in export promotion house and SEZ were entitled to facilities and assistance on customs duty, excise duty and value added tax. The Industrial Enterprises Act 2016 has also recognized the establishment of SEZ for operation of industrial activities in an intensive manner. The Government of Nepal (GoN) had first institutionalized the concept of SEZ in 2013 followed by the enactment of SEZ Act in 2016 (SEZ Act, 2018) which was enacted by the Legislative Parliament and has come into effect from October 4, 2016. The Act has offered numerous facilities for industries that set up within the SEZ. Industries established in SEZ get income tax exemption for five years. Customs duty is waived on raw material imports. Likewise, the government provides a one stop service for registration of industries and entire works in the SEZ. The government provides all basic infrastructures to industries under condition that they have to export $75 \%$ of their production. The Special Economic Zone Regulations - 2017 (2074 B.S.) was enacted by the Parliament which has also various provisions about the SEZ. Latest Special Economic Zone Act (First amendment) 
2075 was introduced with the intention to bring improvements in the legal framework of businessrelated laws and implementation of the revised Act in 2019 for Investment Summit. It has some change in export requirement, Infrastructural setup inside SEZ, rental charge and income tax and tax exemption facility on dividend with respect to previous act. Legally the SEZ of Nepal are very safe and has various facilities but there are lots of problems for the implementation of these legal provisions.

\section{Challenges of SEZ}

The SEZ offers genuine opportunities for increasing exports by accelerating growth in the manufacturing sector. But it has various challenges in developed and developing countries. Out of the 17 proposed SEZs, the Bhairahawa SEZ is the only one that has been materialized so far. Although, the Bhairahawa SEZ was inaugurated on November 2014, the firms haven't been able to commence full-fledged operations till date (Chaudhary, 2018). It indicates the hidden factors have been creating to implement the SEZ. Some of the challenges in the context of Nepal are listed on following points:

1. Infrastructure: Constraints related to land, water and sanitation, road and other infrastructure.

2. Coordination: A SEZ can serve as an effective facilitator for accelerating private investment, especially for enhancing manufacturing growth and generating productive employment. But due to high costs of labour, administrative delays and coordination challenges it cannot be achieve in time.

3. Connectivity: In order for the SEZs to be financially viable, economic corridor development is very essential. ADB (2008) claims that the SEZs connected to its corridors only have to meet national aims, environmental and social standards. Without connectivity, SEZ cannot achieve its goal.

4. Implementations of Law: Due to the structural problems of the state mechanism, various types of laws, acts and regulations will not implement properly. National investment laws, national labor laws and environmental protection laws and other related laws etc. are not facilitating to SEZ.

5. Environmental Assessment: There are no references made as to the obligations of the SEZ to conduct Environmental Impact Assessments, or Environmental Management plans. There are no requirements for monitoring systems to be set in place. Sometimes interna- 
tional measures of EIA constraints to developed new SEZ.

6. Actual benefits in dream: Governments do not scrutinize whether or not the different administrations operate in compliance with environmental, labor and social standards, and SEZs cannot be controlled by trade unions or civil society organizations. The actual benefits of SEZs remain unclear in these cases.

7. Barrier of national fiscal policy: As the ADB stated in a Technical Assistance report for the Laos government in 2008: "While there is a temptation to attract investments by offering special financial incentives rather than building underlying competitive conditions, it should be noted that these approaches have the potential to distort national fiscal policy and hurt environmental and labor standards" (ADB, 2008). It will also repeat in all developing countries including Nepal.

8. Political economy implications for SEZ policy: Governments must aim at creating a robust political economy, in which SEZs are successful despite the inevitable and natural flaws of both government and civil servants. Policy makers need to acknowledge these flaws, and understand the obstacles to SEZ success that they cause.

9. Inadequate knowledge: Government officials face knowledge gaps on several crucial features of new SEZs, including their location, their industry focus, and the combination of features that will attract investors.

10. Global challenges: Global policy uncertainty, fiercer competition for investment, global market competition, Policy implication of INGOs in national context etc are other challenges to SEZ.

11. Failure to deliver world class infrastructure: Some of the biggest challenges faced in African SEZs have resulted from the failure to deliver on promises of world class infrastructure, quality investment environment, etc. (Farole \& Moberg, 2014). It is also common in South Asian SEZ including Nepal.

12. Problems of information dissemination: Not all relevant information concerning the planning and realization of SEZs has been publicly disclosed.

\section{Opportunities of SEZ}

Special economic zone is a multi-sectorial development approach and focus on both national and international markets. It offers a vast incentive including infrastructure, tax and customs 
exemptions and simpler administrative procedures. (Mahmoodabadi, 2018). It creates the multiple opportunities for the economic development of the country. The major aim of SEZ is to increase the export and reduce the trade deficit of the country. Increased employment, more foreign investment, and increased export are the main targets of SEZs (Khatiwada, 2012). It has various opportunities in the country, some of them are mentioned on following points:

1. Tackling spatial inequalities using SEZs: The success of SEZ approach to upgrade a laggard region lies not just in the ability of the state to overcome weaknesses in locational characteristics in such a SEZ, but their ability to create a significant cost advantage for MNEs that agree to establish in such a location. Proper location can boost the economic growth and remove the inequalities among the region and people.

2. Upgrading and linking to the informal economy: Estimates of the share of the population in the informal economy are as high as 88 per cent in South Asia, with 83.4 per cent of employers (Now 70 percent) and 64.5 per cent of employees classified as informal (ILO, 2018) sector in Nepal. It will help to connect this informal sector to formal economy.

3. Enchantment of economic activities: Organizational skills, technological or managerial expertise play a limited role, and few informal actors have access to financial capital that allows them to expand their economic activities (Niraula \& Zhan, 2019). SEZ will enhance this skill, technology and managerial activities in the country.

4. One door policy: The investors in SEZ are granted permission and administered in all respect of export and import under strictly simplified 'One Window Policy' or one stop service which will increases the administrative efficiency and decreases the cost.

5. Low tax facilities: They have liberal tax regime with exemption to varying degrees in income tax, excise duty, VAT and others taxes and duties which will attracts the more investor with and without the country.

6. Relevant facilities and services: They have facilities of repatriation of investment, immigration, banking, export-import facility, foreign workers' employment, etc. It also provides the relevant services such as custom, banking, insurance, police, fire, medical, etc. are at the door.

7. Liberal labor laws: SEZs are governed by liberal production oriented labor law with hire and fire policy forbidding union and strikes. Instead, the labors have wages much higher than outside SEZs, fixed working period and liberal extra benefits and allowances (SEZ, 
2012). It will reduce the movements, strike and other irrelevant activities inside the SEZ territory.

8. Separate policies and laws: SEZ has special laws, acts and policies which will independently works within the SEZ territory. There is no disturbance of the political activities and government instability.

\section{Conclusions}

The Special Economic Zones (SEZ) are constructed to enhance the national and international investment, reduce the barriers of operation, trade enhancement and facilitate to the investors. Most of the countries of the world either developed or developing have practiced the different types of SEZ for their economic development. Nepal has initiated it during the period of 2010s and tried to establish more than 20 national levels SEZ in various parts of the country. Although, these SEZ are still not in functioning but it is expected that they will help to enhance the investment, foreign trade, and industrialization in the country.

\section{References}

ADB (2008). Lao People's Democratic Republic: Building Lao PDR's capacity to develop Special Economic Zones. Retrieved from http://www.adb.org/Documents/TARs/LAO/42032-LAOTAR.pdf (accessed on 31 MAR 2011)

ADB (2018). The role of special Economic Zones in improving effectiveness of greater Mekong sub-region Economic corridors, Asian Development Bank, Philippines

Badal, B.P. (2020). Bhaktapur Tourism, Research Nepal Journal of Development Studies, 3.1, 2956

Baissac, C. (2011). Brief history of SEZs and overview of policy debates DOI: 10.1596/9780821386385_CH02. Retrieved from https://www.researchgate.net/publication/301090540

Bost, F. (2019). Special economic zones: methodological issues and definition. Transnational corporations Volume 26, 2019, Number 2. Retrieved from https://unctad.org/system/ files/official-document/diaeia2019d2a7_en.pdf

Department of Export (2019). Exports transit procedure. Retrieved from http://www.tepc.gov.np/ pages/exports-transit-procedure 
Farole, T. \& Moberg, L. (2014). It worked in China, so why not in Africa? The political economy challenge of Special Economic Zones. World Institute for Development Economics Research wider.unu.edu

Foreign Investment Advisory Service (FIAS). 2008. Special Economic Zones: Performance, lessons learned, and implications for zone development. Washington, DC: World Bank.

Joshi, R. (2073). Bhairahawa Special Economic Zone (SEZ). Retrieved from https://www.seznepal. gov.np/noticedetail.php?id=7

Khanal, R. (2019). Entrepreneurs reluctant to move into Special Economic Zones. Retrieved From the Kathmandu Post

Khatiwada, Y. K. (2012). SEZs focus export industries. Retrieved from https://www.spotlightnepal. com/2012/12/28/sezs-focus-export-industries-baskota/

Mahmoodabadi, M. (2018). Free Economic Zones: pros and cons. Retrieved from https://www. exportiamo.it/aree-tematiche/13729/free-economic-zones-pros-and-cons/

Nepal Intermodal Transport Development Board (2012). NITDB to invite bids to lease out Kakarvitta dry port. Retrieved from The Kathmandu Post

Pakdeenurit, P.; Suthikarnnarunai, N. \& Rattanawong, W. (2014). Special Economic Zone: Facts, roles, and opportunities of investment. In Proceedings of the International MultiConference of Engineers and Computer Scientists 2014, Hong Kong, China.

Pakdeenurit \& Suthikarnnarunai (2017). Special Economic Zone: Facts, roles, and opportunities of investment. Proceedings of the International Multi-Conference of Engineers and Computer Scientists 2014 Vol II, IMECS 2014, March 12 - 14, 2014, Hong Kong

Niraula, R. \& Zhan, J.X. (2019). Using special economic zones to facilitate development: policy implications. Transnational corporations Volume 26, 2019, Number 2

SEZ (2012). Special Economic Zones, MoICS, Tripureshwor, Kathmandu.

SEZ Act (2018). Special Economic Zone (First Amendment) act 2075: A review. Retrieved from https://nepaleconomicforum.org/neftake/special-economic-zone-first-amendment-act2075-a-review-neftake-nepaleconomicforum/

Topno, A. (2005). What is Special Economic Zone? Indiatimes news netwok, https:// 
economictimes.indiatimes.com/news/economy/policy/what-is-special-economic-zone/ articleshow/1164460.cms?utm_source=contentofinterest\&utm_medium=text\&utm_ campaign=cppst

Tripathi, P. (2007). Which is the world's first SEZ? Retrieved from https://timesofindia.indiatimes. com/Which-is-the-worlds-first-SEZ/articleshow/2393897.cms

UNCTAD (2019). World investment report. Retrieved from https://unctad.org/en/ PublicationsLibrary/ wir2019_en.pdf.

UNIDO (2015). Economic Zones in the ASEAN. Retrieved from https://www.unido.org/fileadmin/ user_media_upgrade/Resources/Publications/UCO_Viet_Nam_Study_FINAL.pdf 